\title{
A PANEL DATA ANALYSIS OF FACTORS PUSHING GDP OF MALAYSIA- A RESEARCH ON SELECTED ECONOMIC INDICATORS
}

\author{
Monika Chopra \\ Chandigarh University \\ monikaitft@gmail.com
}

\begin{abstract}
Introduction: From time immemorial, the policy emphasis has always been on Gross Domestic Product (GDP) since it is the measure of wellbeing. Every country's budget is intended to move the economy in the right direction by promoting economic development.

Objective: The study is performed to analyse the long-term impact of select economic indicators from available literature review on economic growth of Malaysia.

Methodology: For meeting the research objective a panel data is famed through data collection from official website of world bank. After collecting data of selected indicators, research tools namely- mean, standard deviation, ANOVA and regression are applied.

Value: The study will lead to an understanding of which important element affects GDP and allows the policymakers to focus their attention on factors relevant to the goal of raising GDP.
\end{abstract}

Keywords: Employment, Export, inflation, FDI, GDP

\section{INTRODUCTION}

Gross Domestic Product indicates the economic well-being of the country. GDP has a rectilinear correlation with economic indicators of the country. This paper analyses the longterm impact of select economic indicators from available literature review on economic growth of Malaysia. The industrial and services industries dominated Malaysia's economy, while the agricultural sector's contribution to economic growth seemed to be minor. It can be explained by the consequences of Malaysia's transition from an agrarian to an industrial economy since the 1970s. The New Economic Policy (NEP) 1970-1990, the National Development Policy (NDP) 1990-2000, and the National Vision Policy (NVP) 2001 have all served as the foundation for Malaysia's economic development plan from the late 1970s. Malaysia is now a high-middleincome country with a diverse economy driven by services (55 percent of GDP) and manufacturing (25 percent), with mining ( $8 \%$ of GDP) and agriculture ( $7 \%$ of GDP) trailing far behind (IMF 2015). It is measured by the annual statistics from 2000 to 2019.

The study is premised on time series data from World bank database. To investigate the association between the dependent variable (GDP) and the independent variables (FDI (foreign direct investment), Exports and inflation), the data was analyzed using Multiple Regression 
Analysis. Exports and Foreign Direct Investment (FDI) are found to be correlated to real GDP per capita, however inflation has non-linear relationship with GDP per capita.

\section{LITERATURE REVIEW}

FDI, export and inflation has focused various empirical literatures on economic development of the country. Various longitudinal studies investigate the relationship and trend between the three independent determinants on GDP. After reviewing previous trends, a number of policies and tactics have been devised to attract additional inflows of income by offering low wages and skilled labor, by leveraging some trade policy constraints, and by rising above income inequality and progressing toward a developed economy.

Different growth models have created the framework for FDI growth. "How does foreign direct investment effect economic growth", according to Borensztein, Governments often view FDI as a subsidy on their own investment because FDI investment is frequently matched by domestic investment. FDI is advantageous to the recipient country since it boosts GDP growth. Productivity increases as a result of the transfer of modern technology and improved working practises if the recipient country's human capital stock is sufficient.[1] This paper examines that Malaysia's economic growth is exceedingly attributed to FDI inflows and human capital build-up. Since 2010, Malaysia's foreign investment has fluctuated between USD 9 billion and USD 12 billion, making it one of the region's top FDI recipients. FDI inflows have dropped in the last two years, according to UNCTAD's World Investment Report 2020, reaching USD 7,6 billion in 2019. In 2019, the stock of FDI was estimated to be over USD 169 billion. Despite pandemic in2020, Malaysia remains a desirable investment destination in the context of global trade concerns.

Inflationary pressures impact domestic R\&D investment and technology growth rates Because a country's economic prosperity is reliant on both domestic and foreign technologies, rising overseas inflation has an impact on the domestic economy. Nash equilibrium inflation rates are often greater than the optimal inflation rates set by cooperative countries who enhance the welfare of both domestic and international households when each country executes its monetary policy unilaterally to optimize the welfare of domestic households.[2] One of the primary hallmarks of the Malaysian economy in the previous two decades has been low inflation and stable GDP growth. Malaysia's inflation rate was surprisingly low by worldwide standards despite its significant economic expansion in the 1980s and 1990s. Malaysia's inflation rate has been reasonably low even after the catastrophic Asian crisis (1997 and 1998) and steep 
depreciation of the ringgit in 1997-98. The past studies suggests existence of a single price level above which inflation has a detrimental impact on economic growth.[3]

Exports are considered to be one of the most important economic indicators to benefit Country's GDP and international trade. Malaysia's economy has changed significantly since1970, and it no longer relies solely on a few essential goods. Malaysia has progressed fast from a commodity economy to a manufacturing and service economy at the same time. As an outcome, Malaysia's economy has been more open to the outside world and has liberalized in a range of aspects.[4]

\section{METHODOLOGY}

For meeting the research objective, a panel data from 1999 to 2019 is famed through data collection from official website of world bank. which was analyzed using SPSS version 20 After collecting data of selected indicators, research tools namely- mean, standard deviation, ANOVA and regression are applied. Secondary data are applicable for this study since it explores the relationship between FDI, export, Inflation and GDP per capita.

Table 1. Regression Result

\begin{tabular}{|l|r|}
\hline \multicolumn{1}{|c|}{$\begin{array}{c}\text { Regression } \\
\text { Statistics }\end{array}$} & \\
\hline Multiple R & 0.925972289 \\
\hline R Square & 0.857424679 \\
\hline $\begin{array}{l}\text { Adjusted R } \\
\text { Square }\end{array}$ & 0.830691807 \\
\hline Standard Error & 0.906750969 \\
\hline Observations & 20 \\
\hline
\end{tabular}

Table 1 reveals that the multiple correlation coefficient between the independent factors and the outcome variable, GDP growth, is $r=0.925$, indicating that the variables are positively correlated. The $\mathrm{R} 2=0.857$ indicates that the independent variables can explain 85.7 percent of the movement in the dependent variable, leaving 14.3 percent unexplained. The modified R2 value of 0.830 indicates how effectively the model generalizes. The differential here between R2 and adjusted R2 is $0.857-0.830=0.027$, signifies the model would account for approximately 2.7 percent less variance in the outcome if it was derived from the population rather than a sample. 
Table 2. Anova Result

ANOVA
\begin{tabular}{|l|c|c|c|c|c|} 
& $d f$ & $S S$ & $M S$ & $F$ & Sig F \\
\hline Regression & 3 & 79.1129652 & 26.3709884 & 32.0738 & $5.32674 \mathrm{E}-07$ \\
\hline Residual & 16 & 13.15515712 & 0.82219732 & & \\
\hline Total & 19 & 92.26812232 & & & \\
\hline
\end{tabular}

The ANOVA F-value is a measure of how well a model performed. Table illustrates the model's statistical significance. At p 0.001, the F-value is regarded statistically significant, implying that the results of the analysis are not due to chance alone.

Table 3. Coefficients

\section{Coefficients}

\begin{tabular}{|c|c|c|c|c|c|c|}
\hline & $\begin{array}{l}\text { Coefficient } \\
s\end{array}$ & $\begin{array}{l}\text { Standard } \\
\text { Error }\end{array}$ & t Stat & $P$-value & $\begin{array}{l}\text { Lower } \\
95 \%\end{array}$ & $\begin{array}{l}\text { Upper } \\
95 \%\end{array}$ \\
\hline Intercept & $\begin{array}{l}2.2066501 \\
68\end{array}$ & $\begin{array}{l}0.6315282 \\
9\end{array}$ & 3.494143021 & 0.003 & $\begin{array}{l}0.8678699 \\
99\end{array}$ & $\begin{array}{l}3.5454 \\
3\end{array}$ \\
\hline $\begin{array}{l}\text { Foreign direct } \\
\text { investment, net } \\
\text { inflows (\% of GDP) }\end{array}$ & $\begin{array}{l}0.6193616 \\
69\end{array}$ & $\begin{array}{l}0.2217813 \\
16\end{array}$ & 2.792668386 & $\begin{array}{l}0.0130 \\
37\end{array}$ & $\begin{array}{l}0.1492062 \\
83\end{array}$ & $\begin{array}{l}1.0895 \\
17\end{array}$ \\
\hline $\begin{array}{l}\text { Exports of goods and } \\
\text { services (annual \% } \\
\text { growth) }\end{array}$ & $\begin{array}{l}0.2047814 \\
37\end{array}$ & $\begin{array}{l}0.0530131 \\
91\end{array}$ & 3.862839276 & $\begin{array}{l}0.0013 \\
78\end{array}$ & $\begin{array}{l}0.0923984 \\
92\end{array}$ & $\begin{array}{l}0.3171 \\
64\end{array}$ \\
\hline $\begin{array}{l}\text { Inflation, GDP deflator } \\
\text { (annual \%) }\end{array}$ & $\begin{array}{l}0.0312269 \\
83\end{array}$ & $\begin{array}{l}0.0889547 \\
85\end{array}$ & 0.351043323 & $\begin{array}{l}0.7301 \\
36\end{array}$ & $\begin{array}{l}- \\
0.1573487 \\
36\end{array}$ & $\begin{array}{l}0.2198 \\
03\end{array}$ \\
\hline
\end{tabular}

When the predictor variable under examination grows by one and all other independent variables remain constant, the regression coefficient tells how much the dependent variable GDP is predicted to increase. FDI and exports are significant at $\mathrm{p}<0.05$.

\section{FINDINGS AND CONCLUSIONS}

Therefore, the policy implications of this study include that it is preferable to keep inflation below the threshold level in Malaysia, implying that the link between inflation and economic growth in Malaysia is non-linear, and that inflation below 3.89 percent can sustain economic growth. When inflation exceeds 3.89 percent, on the other hand, it is damaging to economic growth. In addition, government initiatives should be formulated to attract more FDI and boost trade, generate employment thereby enhancing Malaysia a massively lucrative economy for international investment. 


\section{References}

[1] N. E. Douglas, "What is the evidence on the role of foreign direct investment in economics growth, and on the determinants of foreign direct investment flows," Direct, no. 13651, 2006, [Online]. Available: http://mpra.ub.uni-muenchen.de/13651/.

[2] A. C. Chu, G. Cozzi, C. C. Lai, and C. H. Liao, "Inflation, R\&D and growth in an open economy," J. Int. Econ., vol. 96, no. 2, pp. 360-374, 2015, doi: 10.1016/j.jinteco.2015.03.007.

[3] Q. Munir and K. Mansur, "Non-linearity between inflation rate and GDP growth in Malaysia,” Econ. Bull., vol. 29, no. 3, pp. 1551-1565, 2009.

[4] L. S. Yee, H. WaiMun, T. Zhengyi, L. J. Ying, and K. K. Xin, "Determinants of Export: Empirical Study in Malaysia,” J. Int. Bus. Econ., vol. 4, no. 1, pp. 61-75, 2016, doi: 10.15640/jibe.v4n1a6. 